\title{
A Study on the Prolactin Receptor 3 (PRLR3) Gene and the Retinol-binding Protein 4 (RBP4) Gene as Candidate Genes for Growth and Litter Size Traits of Berkshire in Korea
}

Chang-Hee Do, Seon-Ku Kim ${ }^{1}$, Han-Suk Kang ${ }^{1}$, Teak-Soon Shin ${ }^{1}$, Hong-Gu Lee ${ }^{1}$, Seong-Keun Cho ${ }^{1}$, Kyung-Tak Do ${ }^{1}$, Ji-Na Song ${ }^{1}$, Tae-Hun $\mathrm{Kim}^{2}$, Bong-Hwan $\mathrm{Choi}^{2}$, Byung-Chan Sang, Yeong-Kuk Joo ${ }^{3}$, Jun-Kyu Park ${ }^{3}$, Sung-Hoon Lee ${ }^{3}$, Jeong-III Lee ${ }^{3}$, Jeong-Suk Park ${ }^{3}$, Young-Soo Sin ${ }^{4}$, Byung-Woo Kim ${ }^{5}$ and Byung-Wook Cho ${ }^{1 *}$

Department of Animal Biosystem Science, Chungnam National University, Daejeon 305-764, Korea

${ }^{1}$ Department of Animal Science, Pusan National University, Miryang 627-706, Korea

${ }^{2}$ Animal Genomics and Bioinformatics Division, National Livestock Research Institute, RDA, Suwon 441-706, Korea

${ }^{3}$ Gyeongnam Livestock Veterinary Research Institute, Sancheong 666-962, Korea

${ }^{4}$ Department of Animal Science, Shingu University, 657 Gwangmyeong-ro, Seongnam 462-743, Korea

${ }^{5}$ Institute of Agriculture \& Life Sciences, Gyeongsang National University, Jinju 660-701, Korea

Received February 22, 2010 / Accepted May 7, 2010

Two diallelic markers at candidate gene loci, the prolactin receptor 3 (PRLR3) gene and the retinol-binding protein 4 (RBP4) gene were evaluated for their association with growth and litter size traits in Berkshire. Genetic evaluation was conducted for 5,919 pigs with pedigree information, which included 3,480 growth performance records and 775 litter size records of 224 sows. From the same herd, genotyping was carried out on 144 and 156 animals for PRLR3 and RBP4, respectively. After assigning a genotype to subjects in which both parents had a homozygous genotype, numbers of genotyped animals increased to 474 and 338, for the PRLR3 gene and RBP4 gene, respectively. The genotype effects of two markers were estimated with breeding values of the genotyped animals. The additive effects of total number of piglets born and number of piglets born alive in the PRLR3 locus were -0.28 and -0.13 , respectively. The dominance effect of the RBP4 locus on average daily gain was -10.58 g. However, the polymorphism of the RBP4 locus in total number of piglets born and number of piglets born alive has shown -0.34 and -0.33 of the additive genetic effects. In view of the results, MAS (marker-assisted selection) favoring B alleles of RBP4 and PRLR3 loci could potentially accelerate the rate of the genetic improvement in the litter size traits.

Key words : Berkshire, prolactin receptor 3 (PRLR3), retinol-binding protein 4 (RBP4), additive effect, marker-assisted selection

\section{Introduction}

The candidate gene approach is one of methods to identify genes or markers linked to quantitative traits. It employs biological information of individual genes from other species and selects the genes for the investigation. Once polymorphism is identified in candidate genes, further investigation is carried out to find the relationship of the gene or marker with traits of interest. Using candidate gene analysis, several major genes such as melanocortin 4 receptor (MC4R) [11] for growth, ryanodine receptor (RYR1) [6], and heart fatty acid binding protein (HFABP) [7] for meat quality

\footnotetext{
*Corresponding author

Tel : +82-55-350-5510, Fax : +82-55-350-5519

E-mail : bwcho@pusan.ac.kr
}

have been identified for their association with economic traits. Researchers are able to analyze candidate genes with performance test records in traits of interest even in larger population. More accurate allelic effects can be estimated with large size of data. Once an association of the candidate genes with traits is found, the gene test has immediate use in marker-assisted selection (MAS) for genetic improvement of the population. However, the relationship between the genes and the traits should be re-estimated, as the size of data increases.

Selection had been practiced to eliminate the recessive allele (n) of Halothane gene in Korea from 2002 to 2005. This project was carried out for pork quality, and it was subsidized by the government. Alleles at the prolactin receptor gene (PRLR) locus, and the retinol-binding protein 4 gene 
(RBP4) locus have been associated with significant differences in litter size in pigs $[15,19]$. If the reliable information about additive and dominance effects of each marker is available, MAS in conjunction with traditional selection methods could be more effective for improving accuracy, reducing the generation interval, and accelerating the genetic improvement of the traits. The objectives of this study were to obtain genetic information of prolactin receptor 3 (PRLR3) gene, and retinol-binding protein 4 (RBP4) gene on litter size and growth traits in Berkshire breed of pigs.

\section{Materials and Methods}

\section{Animals and DNA isolation}

A total of 5,919 Berkshire pigs with known pedigree information were included in the genetic evaluation. Number of piglets born alive (NBA) and total number born (TNB) were recorded in 775 litters of 224 sows. There were 3,480 animals with the records of back fat thickness $(\mathrm{BF})$, days to $90 \mathrm{~kg}$ (D90kg) and average daily gain (ADG), which were measured at around 155 days of age and calculated by the growth curves for Berkshire breed [2] (Table 1). Blood samples from the pigs were used for DNA isolation with the Toyobo MagExtraction Kit (Toyobo).

\section{Primer design and polymerase chain reaction}

A total of 2 primer sets were analyzed for RFLP genotyping of 2 candidate genes (PRLR3 and RBP4). Amplification of fragments of the Berkshire pigs PRLR3 and RBP4 genes was obtained using the following primer pairs:

PRLR3 : forward 5'-CGT GGC TCC GTT TGA AGA ACC-3' reverse $5^{\prime}$-CTG AAA GGA GTG CAT AAA GCC-3'

RBP4 : forward 5'-GAG CAA GAT GGA ATG GGT T-3' reverse $5^{\prime}$-CTC GGT GTC TGT AAA GGT G-3'

Polymerase chain reactions were performed in $10 \mu \mathrm{l}$ vol- umes contained $12 \mathrm{ng}$ of genomic DNA, $10 \mathrm{pmol}$ of each primer, $200 \mu \mathrm{M}$ of each dNTP, 2.5 units of Taq DNA polymerase (Enzynomics ${ }^{\mathrm{TM}}$, Korea), and reaction buffer with 1.5 $\mathrm{mM} \mathrm{MgCl}_{2}$. Thermocycling reaction was performed in a PTC-200 thermocycler (MJ Research, Watertown, MA, USA) with a 5 min initial denaturation at $94^{\circ} \mathrm{C}, 45 \mathrm{~s}$ at annealing temperature and $60 \mathrm{~s}$ at $72^{\circ} \mathrm{C}$, and a final extension for 10 $\min$ at $72^{\circ} \mathrm{C}$.

\section{Polymorphism identification and genotyping}

Polymorphic sites were analyzed for restriction fragment length polymorphisms (RFLPs) using the NEBcutter program. Genotyping was performed on individual DNA samples from the Berkshire breed. All restriction enzymes were supplied by New England BioLabs (Ipswich, MA, USA) and restriction digestions were performed according to perform as previously described [15].

The PCR product was digested with $8 \mathrm{U}$ Alu I (N.E.B.) and separated on a 3\% Metaphor (FMC) agarose gel such that 85-bp, 59-bp, and 19-bp fragments were observed for the AA genotype and 104-bp and 59-bp fragments for the BB genotype and Digestion of the remaining PCR product with $4 \mathrm{U}$ of Msp I produce fragments that separated on 3\% Metaphor (FMC) gel such that 190-bp, 154-bp, and 136-bp fragments were observed for AA genotype, and 154-bp, 136-bp, and 125-bp, fragments for BB genotype.

\section{Statistical analysis}

The additive genetic relationship matrix for the Best Linear Unbiased Prediction (BLUP) animal model includes pedigree information up to 6 generations. The linear animal model for litter size traits was employed as follows:

$Y_{i j k}=\mu+F Y M_{i}+A_{j}+F_{j k}+E_{i j k}$

For the analyses of all available litter size records from different parities of a sow, the models include parity (FP)

Table 1. Distribution of records for litter size and growth traits

\begin{tabular}{|c|c|c|c|c|c|c|c|c|c|}
\hline \multicolumn{4}{|c|}{ Litter size traits } & \multicolumn{6}{|c|}{ Growth traits } \\
\hline \multicolumn{2}{|c|}{ Farrowing year } & \multicolumn{2}{|c|}{ Parity } & \multicolumn{2}{|c|}{ Birth year } & \multicolumn{2}{|c|}{ Gender } & \multicolumn{2}{|c|}{ Parity } \\
\hline 2003 & 110 & 1 & 231 & 2003 & 630 & Female & 2,112 & 1 & 1,143 \\
\hline 2004 & 183 & 2 & 159 & 2004 & 951 & Male & 975 & 2 & 701 \\
\hline 2005 & 213 & 3 & 119 & 2005 & 864 & Castrated & 393 & 3 & 586 \\
\hline 2006 & 179 & 4 & 95 & 2006 & 1,003 & & & 4 & 451 \\
\hline \multirow[t]{4}{*}{2007} & 90 & 5 & 71 & 2007 & 32 & & & 5 & 218 \\
\hline & & 6 & 51 & & & & & 6 & 212 \\
\hline & & 7 & 29 & & & & & 7 & 102 \\
\hline & & $\geq 8$ & 20 & & & & & $\geq 8$ & 67 \\
\hline
\end{tabular}


of sow and year-month-seasonal classes (FYM) at farrowing as fixed effects. The random effects were genetic effect (A) of the animal and residual effect (E). For the analysis of back fat thickness $(\mathrm{BF})$, average daily gain (ADG), and days to 90kg (D90kg), the following linear model was employed:

$$
Y_{i j k l}=\mu+B Y M_{i}+G_{j}+D P_{k}+A_{1}+E_{i j k l}
$$

Year-month-seasonal classes at birth (BYM), gender (G), and dam's parity (DP) were regarded as fixed effects. Genetic effect (A) of animals and residual effect (E) were treated as random effects. Genetic evaluation of litter size and growth traits were carried out using MTDFREML (USDA, 2006). The genotype effects of the markers from genetic effects of animals were estimated by GLM procedure of SAS (2001). Additive genetic effects for the genetic markers were estimated by pair-wise comparison of the two homozygous genotypes, and the dominance effects were calculated as the deviation of the heterozygote effect from the average of the two homozygous genotypes.

\section{Results and Discussion}

The Berkshire pigs were reared under intensive selection on the productive and reproductive traits at Gyeongnam Swine Research Institute from year 2003 to 2007. About 20 live boars and 100 live sows were maintained in the herd during that period. Computer mating program was utilized to avoid high inbreeding and to achieve maximization of genetic improvement in economical traits. Consequently estimated average inbreeding coefficient was as low as $1.6 \%$. No permanent environmental effects of sows were included in the model for repeated litter size records over productive life of sows. It may lead to biased estimation of animal effects. However, it was assumed that the permanent environmental effects are mostly absorbed by residual effects (E) in the equation 1 . The animal genetic effects are sums of additive genetic effects of all genes in the genome related with a certain trait, which are estimated by BLUP Animal Model and referred to as breeding values in animal breeding
[9]. The genotype effects were calculated with the breeding values of the animals identified for the genotypes of genetic markers. The accuracy of breeding values, however, is important for accurate estimation of genotype effects and further statistical inference for justification of this approach may be necessary. Even so, this method gives better connectedness and easy computation in estimation of the genotype effects. When a trait such as litter size is expressed only in female, available sows for genotyping of a marker are often limited and it is insufficient to estimate genotype effects only with them. The breeding values of all animals for such trait can be estimated with good shape in connectedness, and then the genotype effects can be easily calculated only with the animals genotyped for the marker including even males.

Summary statistics for litter size and growth traits are shown in Table 2. The male pigs castrated at birth showed higher average daily gain than other pigs. The average of number of piglets born alive was 7.45, which is small comparing with Landrace and Yorkshire breeds [18]. An overview of the frequency of animals according to genotypes is given in Table 3. PRLR3 and RBP4 loci showed polymorphism in the Berkshire herd(Fig. 1, 2). When the genotypes of both parents are homozygote, a genotype can be assigned to their offspring. Numbers of the animals assigned by pedigree information were 195 and 318 for PRLR3 and RBP4, respectively. Hardy-Weinberg equilibrium was checked with the number of animals genotyped. The frequency of A allele in PRLR3 locus was 0.50 and that of B allele was

Table 3. Numbers of animals according to genotypes of the candidate gene markers (PRLR3, and RBP4)

\begin{tabular}{|c|c|c|c|c|c|c|c|c|}
\hline & \multicolumn{4}{|c|}{ PRLR3 } & \multicolumn{4}{|c|}{ RBP4 } \\
\hline & AA & $\mathrm{AB}$ & BB & Total & AA & $\mathrm{AB}$ & BB & Total \\
\hline Genotyped & 22 & 101 & 21 & 144 & 34 & 54 & 68 & 156 \\
\hline Assigned $^{1}$ & 0 & 160 & 35 & 195 & 62 & 118 & 138 & 318 \\
\hline Total & 22 & 261 & 56 & 339 & 96 & 172 & 206 & 474 \\
\hline
\end{tabular}

${ }_{1}^{1}$ represents increment of animals identified by genotyping with parent information

Table 2. Summary statistics for the litter size and growth traits

\begin{tabular}{|c|c|c|c|c|c|c|c|}
\hline \multicolumn{3}{|c|}{ Litter size traits } & \multicolumn{5}{|c|}{ Growth traits } \\
\hline Head & TNB & NBA & Gender & Head & $\mathrm{BF}(\mathrm{mm})$ & ADG $(\mathrm{g})$ & D90kg (day) \\
\hline 224 & & & Female & 2,112 & $17.6 \pm 0.18$ & $566.9 \pm 1.4$ & $158.6 \pm 0.36$ \\
\hline (775) & 9.39 & 7.45 & Male & 975 & $16.9 \pm 0.13$ & $597.9 \pm 2.2$ & $151.9 \pm 0.49$ \\
\hline & \pm 0.09 & \pm 0.09 & Castrated & 393 & $17.3 \pm 0.19$ & $615.1 \pm 3.2$ & $148.0 \pm 0.65$ \\
\hline
\end{tabular}

The figure and letters in parentheses are number of records and units of traits. 


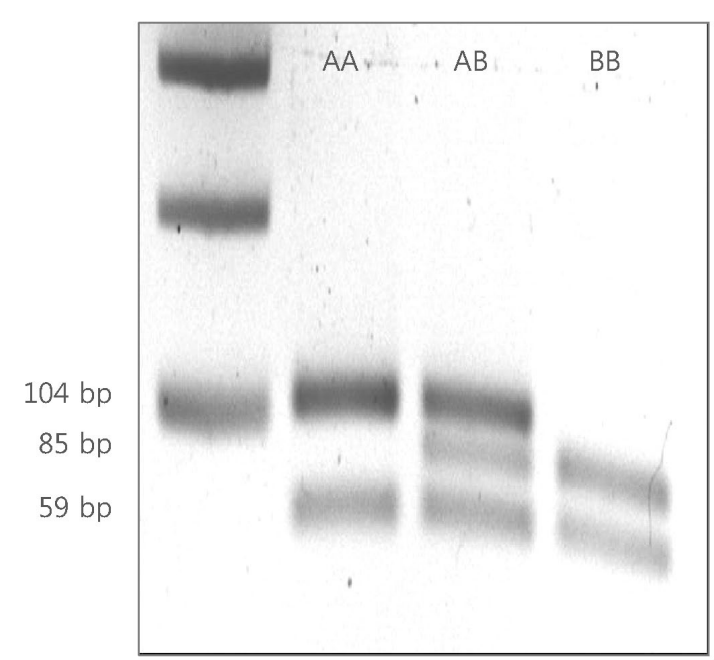

Fig. 1. The PCR-RFLP test for the prolactin receptor 3 polymorphism.

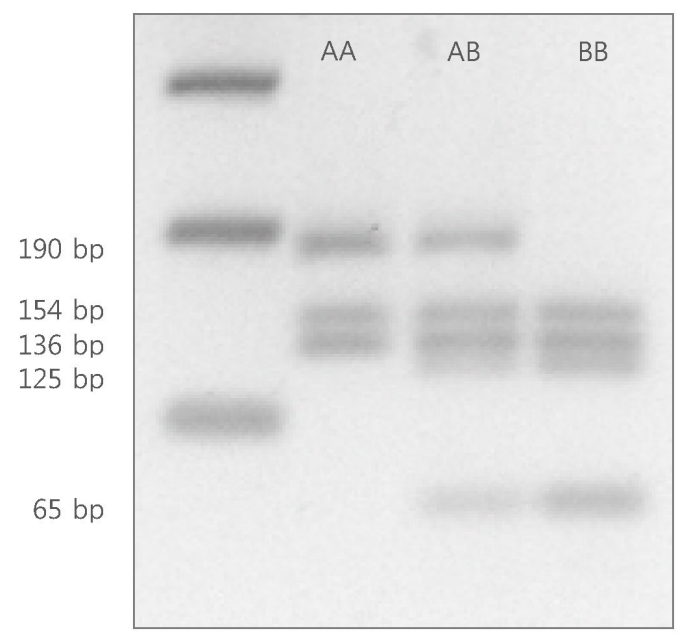

Fig. 2. The PCR-RFLP test for retinol-binding protein 4 polymorphism.

0.50 (Fig. 1). The frequency of A allele in RBP4 locus was 0.42 and that of B allele was 0.58 (Fig. 2). Neither locus was in Hardy-Weinberg equilibrium. It is conjectured that intense selection on production and reproduction traits in the herd was the cause of this disequilibrium [5]. The Berkshire herd exhibited a large number of animals with the AB genotypes of PRLR3 locus and a small number of animals with the $\mathrm{AB}$ genotypes of RBP4 locus than was expected from the Hardy-Weinberg principle.

Additive and dominance effects were estimated with contrasts of three genotypes ( $\mathrm{AA}, \mathrm{AB}$, and $\mathrm{BB})$. The effects of the genotypes in PRLR3 locus were mostly significant for litter size traits (Table 4). All effects with respect to PRLR locus on growth traits were economically trivial and insignificant as shown in Table 4. All estimates of AA genotype were not significant partly due to the lack of AA animals. A difference of 0.56 head in TNB between homozygous genotypes was obtained. Additive effect of B allele of PRLR3 locus in TNB, the favorable allelic substitution effect, was 0.28 piglets. $\mathrm{BB}$ animals had an advantage of 0.27 pigs per litter in NBA, compared with AA animals. The results in the current study on litter size traits were similar with commercial line and Duroc breed [3]. It was already stated that the number of endometrial prolactine receptors influence $\mathrm{PGF}_{2 \mathrm{a}}$ secretion during the early pregnancy, and suggested that $B$ allele positively influenced the number of fetuses per uterine horn [10, 13]. However, it is not known whether PRLR3 is a major gene for litter size or only a linked marker to unknown QTL (quantitative trait locus). They were pointed that there is some distance between the marker and QTL [10]. Different linkage disequilibrium due to different distances according to populations, lines and families may lead to variation in associations between the marker and traits [4].

The effects of the genotypes in RBP4 locus were significant for litter size traits. For growth traits, significances were observed in F-values due to RBP4 genotypes (Table 5). The homozygous animals in RBP 4 gene had a rather

Table 4. Least square means of genotypes and additive effects (a) of allele B and dominance effects (d) in prolactin receptor 3 (PRLR3) gene with respect to litter size and growth traits

\begin{tabular}{|c|c|c|c|c|c|c|}
\hline \multirow{2}{*}{ Trait } & \multicolumn{4}{|c|}{ Genotype effects } & \multicolumn{2}{|c|}{ Genetic effects } \\
\hline & $\mathrm{AA}$ & $\mathrm{AB}$ & BB & F-value & $\mathrm{a}$ & $\mathrm{d}$ \\
\hline $\mathrm{BF}(\mathrm{mm})$ & $-0.11 \pm 0.14$ & $-0.13 \pm 0.04^{\mathrm{a}}$ & $-0.04 \pm 0.08$ & 0.37 & 0.03 & -0.05 \\
\hline D90kg (day) & $-1.87 \pm 1.58$ & $-2.25 \pm 0.46^{\mathrm{a}}$ & $-2.34 \pm 0.99^{b}$ & 0.03 & -0.24 & -0.14 \\
\hline ADG $(g)$ & $8.82 \pm 6.15$ & $9.73 \pm 1.78^{\mathrm{a}}$ & $9.41 \pm 3.82^{b}$ & 0.01 & 0.30 & 0.61 \\
\hline TNB (head) & $0.16 \pm 0.14$ & $0.34 \pm 0.04^{\mathrm{a}}$ & $0.72 \pm 0.09^{\mathrm{a}}$ & $9.96^{\mathrm{a}}$ & 0.28 & -0.11 \\
\hline NBA (head) & $0.14 \pm 0.09$ & $0.24 \pm 0.03^{\mathrm{a}}$ & $0.41 \pm 0.06^{\mathrm{a}}$ & $4.33^{\mathrm{b}}$ & 0.13 & -0.03 \\
\hline
\end{tabular}

${ }^{a}$ and ${ }^{b}$ represent significant at the level of $1 \%$ and $5 \%$, respectively.

F-value designates $\mathrm{F}$ statistics due to genotypes in ANOVA. 
Table 5. Least square means of genotypes and additive effects (a) of allele B and dominance effects (d) in retinol-binding protein 4 (RBP4) gene with respect to litter size and growth traits

\begin{tabular}{|c|c|c|c|c|c|c|}
\hline \multirow{2}{*}{ Trait } & \multicolumn{4}{|c|}{ Genotype effects } & \multicolumn{2}{|c|}{ Genetic effects } \\
\hline & $\mathrm{AA}$ & $\mathrm{AB}$ & BB & F-value & $\mathrm{a}$ & $\mathrm{d}$ \\
\hline $\mathrm{BF}(\mathrm{mm})$ & $0.04 \pm 0.07$ & $-0.11 \pm 0.05^{b}$ & $-0.21 \pm 0.05^{\mathrm{a}}$ & $4.31^{\mathrm{b}}$ & -0.13 & -0.02 \\
\hline D90kg (days) & $-4.81 \pm 0.78^{\mathrm{a}}$ & $-2.90 \pm 0.59^{\mathrm{a}}$ & $-6.51 \pm 0.54^{\mathrm{a}}$ & $10.08^{\mathrm{a}}$ & -0.85 & +2.76 \\
\hline $\mathrm{ADG}(\mathrm{g})$ & $19.51 \pm 3.00^{\mathrm{a}}$ & $11.44 \pm 2.27^{\mathrm{a}}$ & $24.53 \pm 2.07^{\mathrm{a}}$ & $9.10^{\mathrm{a}}$ & 2.51 & -10.58 \\
\hline TNB (head) & $0.18 \pm 0.07^{\mathrm{a}}$ & $0.55 \pm 0.05^{\mathrm{a}}$ & $0.87 \pm 0.05^{\mathrm{a}}$ & $38.69^{a}$ & 0.34 & 0.02 \\
\hline NBA (head) & $-0.08 \pm 0.04^{b}$ & $0.34 \pm 0.03^{\mathrm{a}}$ & $0.57 \pm 0.03^{\mathrm{a}}$ & $81.02^{\mathrm{a}}$ & 0.33 & 0.09 \\
\hline
\end{tabular}

${ }^{\mathrm{a}}$ and ${ }^{\mathrm{b}}$ represent significant at the level of $1 \%$ and $5 \%$, respectively.

$\mathrm{F}$-value designates $\mathrm{F}$ statistics due to genotypes in ANOVA.

small superiority in D90kg and ADG over the heterozygous animals. Favorable additive effects of the B allele were detected for either litter size or growth traits. The results of the association analyses for growth traits showed significance, but the size of additive effects was economically negligible. Significant differences were found among the three RBP4 genotypes in TBN and NBA. The differences calculated between homozygous genotypes reached 0.69 and 0.65 head in TBN and NBA, respectively. Hence, additive effects of RBP 4 gene $B$ allele were 0.34 and 0.33 in TBN and NBA, which were greater than those of PRLR3 gene $B$ allele. It was stated that the expression of retinol-binding protein 4 (RBP4) gene was increased in gravid porcine and Retinolic acid (Vitamin A) derived from endogenous retinol is delivered to target cells by RBP [8]. It may influence embryonic mortality rate [16]. They showed that supplementing the diet of pregnant sows with vitamin A can increase litter size $[1,8]$. This allows us to consider RBP4 gene as a candidate gene of litter size [20]. The genotypic effects of RBP4 gene of Berkshire pigs were significant (Table 5), which were different from the results in the commercial lines [15]. This may be due to different linkage disequilibrium of Berkshire herd [3].

PRLR3 and RBP4 polymorphisms in MAS must be used with caution until further investigations ensure that there are no negative pleiotropic effects with other important traits. Additive and dominance effects of a candidate gene could be different in other breeds or populations [17]. Even though continuous investigation for candidate genes is necessary, the results in the present study could be utilized for MAS of litter size traits in different breed or Berkshire population in Korea. As more associations between candidate genes and traits are identified, MAS will be more useful tool in the genetic improvement of swine. This technology combined with the conventional performance test for pigs seems to be promising for future swine genetic improvement.

\section{Acknowledgement}

We would like to acknowledge the financial support from the Rural Development Administration (2008-01-85000) for the current study and preparation of the manuscript.

\section{References}

1. Brief, S. and B. P. Chew. 1985. Effects of vitamin A and $\beta$-carotene on reproductive performance in gilts. J. Anim. Sci. 60, 998-1004.

2. Do, C. H. 2007. Estimation of growth traits using growth curve in Gyungnam-heugdon (Berkshire). J. Anim. Sci. $\mathcal{E}$ Technol. (Kor.) 49, 195-202.

3. Drogemuller, C., H. Hamann, and O. Distl. 2001. Candidate gene markers for litter size in different German pig lines. J. Anim. Sci. 79, 2565-2570.

4. Du, F., A. C. Clutter, and M. M. Lohuis. 2007. Characterizing Linkage Disequilibrium in Pig Populations Int. J. Biol. Sci. 3, 166-178.

5. Falconer, D. S. 1981. Introduction to Quantitative Genetics. pp. 18-20, Longman Scientific and Technical.

6. Fujii, J., K. Otus, F. Zorzto, S. ED Leon, V. K. Khanna, V. K., Weiler, P. J. O'Brien, and D. H. MacLennan. 1991. Identification of a mutation in porcine ryanodine receptor associated with malignant hyperthermia. Sci. 253, 448-451.

7. Gerbens, F., A. J. van Erp, F. L. Harders, F. J. Verburg, T. H. Meuwissen, J. H. Veerkamp, and M. F. te Pas. 1999. Effect of genetic variants of the heart fatty acid-binding protein gene on intramuscular fat and performance traits in pigs. J. Anim. Sci. 77, 846-852.

8. Harney, J. P., T. L. Ott, R. D. Geisert, and F. W. Bazer. 1993. Retinolbinding protein gene expression in cyclic and pregnant endometrium of pigs, sheep, and cattle. Biol. Reprod. 49, 1066-1073.

9. Henderson, C. R. 1973. Sire evaluation and genetic trends. Proceeding of the Animal Breeding and Genetics Symposium in honor of Dr. Jay L. Lush. July 29, 1972, Virginia 
Polytechnic Institute and State University, Blacksburg, Virginia.

10. Isler, B. J., K. M. Ervin, M. F. Rothchild, and G. J. Evans. 2000. Association between the prolactine receptorgene and reproductive components in swine. Proceeding of the $27^{\text {th }}$ International Conference on Animal Genetics, 27, pp. 67, Minneapolis, Etats-Unis.

11. Kim, K. S., N. Larsen, T. Short, G. Plastow, and M. F. Rothschild. 2000. A missense variant of the porcine melanocortin-4 receptor (MC4R) gene is associated with fatness, growth, and feed intake traits. Mann. Genome. 149, 1069-1080.

12. Mileham, J. and G. S. Plastow. 1997. Effect of the estrogen receptor locus on reproduction and production traits in four commercial pig lines. J. Anim. Sci. 75, 3138-3142.

13. Pope, W. F. 1994. Embryonic mortality in swine, pp. 53-57, In Zavy, M. T. and R. D. Geisert (eds.), Embryonic Mortality in Domestic Species. CRC Press, Boca Raton.

14. Rothschild, M. F. 1998. Identification of quantitative trait loci and interesting candidate genes in the pig: Progress and prospects. Proceeding of 6th World Congress on Genetic Application of the Livestock Production, Armidale, NSW, Australia. 26, 403-409.

15. Rothschild, M. F., L. Messer, A. Day, R. Wales, T. Short, O. Southwood, and G. Plastow. 2000. Investigation of the retinol-binding protein 4 (RBP4) gene as a candidate gene for increased litter size in pigs. Mamm. Genome 11, 75-77.

16. Santos-Guzman, J., T. Arnhold, H. Nau, C. Wagner, S. H. Fahr, G. E. Mao, M. A. Caudill, J. C. Wang, S. M. Henning, M. E. Swendseid, and M. D. Collins. 2003. Antagonism of hypervitaminosis; An induced anterior neural tube closure defects with a methyl-donor deficiency in murine wholeembryo culture. J. Nutr. 133, 3561-3570.

17. Short, T. H., M. F. Rothschild, O. I. Southwood, D. G. McLaren, A. de Vries, H van der Steen, G. R. Steen, G. R. Eckhardt, C. K. Tuggle, J. Helm, and D. A. Vaske. 2006. MTGSAM and MTDFREML. http://www.aipl.arsusda.gov/curtvt/.

18. Varona, L., D. Sorensen, and R. Thompson. 2007. Analysis of Litter Size and Average Litter Weight in Pigs Using a Recursive Model. Genetics 177, 1791-1799.

19. Vincent, A. L., G. Evans, T. H. Short, O. I. Southwood, G. S. Plastow, C. K. Tuggle, and M. F. Rothschild. 1998. The prolactin receptor gene is associated with increased litter size in pigs. Proceeding of 6th World Congress on Genetic Application of the Livestock Production, Armidale, NSW, Australia. 27, 15-18.

20. Zhu, M. and S. Zhao. 2007. Candidate Gene Identification Approach: Progress and Challenges. Int. J. Biol. Sci. 3, $420-427$.

\title{
초록 : 국내 버크셔 돼지에서 성장 및 산자수의 후보유전자로서 PRLR3와 RBP4에 관한 연구
}

\author{
도창희 · 김선구 ${ }^{1}$ 강한석 ${ }^{1} \cdot$ 신택순 $^{1} \cdot$ 이홍구 ${ }^{1} \cdot$ 조성근 $^{1} \cdot$ 도경탁 $^{1} \cdot$ 송지나 $^{1} \cdot$ 김태헌 ${ }^{2} \cdot$ 최봉환 $^{2} \cdot$ 상병찬 $\cdot$ 주영 \\ 국 $^{3} \cdot$ 박준규 $^{3} \cdot$ 이성훈 ${ }^{3} \cdot$ 이정일 ${ }^{3} \cdot$ 박정석 $^{3} \cdot$ 신영수 $^{4} \cdot$ 김병우 $^{5} \cdot$ 조병욱 $^{1 *}$ \\ (충남대학교 동물바이오시스템과학과, ${ }^{1}$ 부산대학교 동물생명자원과학과, ${ }^{2}$ 축산과학원 동물유전체과, ${ }^{3}$ 경남 \\ 축산진흥연구소, ${ }^{4}$ 신구대학교 자원동물과, ${ }^{5}$ 경상대학교 농업생명과학연구원 \& 동물유전·육종연구실)
}

본 연구는 버크셔 품종에서 PRLR3와 RBP4 후보유전자의 두 개의 대립유전자가 산육형질과 번식형질에 미치 는 영향을 조사하였다. 5,919 두의 혈통자료, 3,480 두의 산육기록과, 244 두의 모돈의 775 마리의 산자기록을 이용하 여 유전능력 평가를 수행하였다. 유전자형 분석은 144 두와 156 두에서 PRLR3와 RBP4 유전자의 유전자형을 각각 분석하였다. 평가된 개체들의 육종가를 이용 두 마커의 유전자형 효과와 유의 확률을 추정한 결과 PRLR3 유전자 는 번식형질의 총산자수(TBN)와 생존산자수(NBA)에서 -0.28 과 -0.13 두의 상가적 효과를 각각 나타내었다. RBP4 유전자는 일당증체량에서 $10.58 \mathrm{~g}$ 의 우성적 효과를 나타내었다. 그러나 RBP4 유전자의 다형성은 번식형질의 총 산자수(TBN)와 생존산자수(NBA)에서 - 0.34 와 -0.33 두의 상가적 유전적 효과를 각각 나타났다. 따라서 PRLR3와 $\mathrm{RBP}$ 의 B 대립유전자를 선호하는 MAS (Marker Assist Selection) Scheme은 버크셔 품종의 산자수의 개량에 이용 할 수 있을 것이다. 